DOI: 10.12731/2658-6649-2021-13-3-321-331

UDC 338.43.02

\title{
CONCEPTUAL APPROACHES \\ TO THE DEVELOPMENT OF THE AGRICULTURAL SECTOR IN TERMS OF THE CLOSED-CYCLE ECONOMY
}

\author{
N.A. Prodanova, A.A. Savin, S.N. Kosnikov, I.V. Sorgutov
}

The current stage of development of the agricultural industry is characterized by high rates of automation of production processes. In this regard, the problem of rationalizing the process of distributing agricultural resources and organizing the production chain with added value is becoming more acute. An effective solution to this problem can be a closed-cycle economy model. This model can contribute to the rational use of resources, reduce production losses, and, as a result, improve the quality of products and their volumes. It is necessary to develop a general plan for the implementation of the main postulates of the closed-cycle economy in agriculture, gradually implement the circular economy strategy and include new industrial circular economy in the process of modernization of a particular branch of agriculture. In some areas of agriculture, a cycle of production systems should be established as soon as possible. With the basic implementation of new industrial technologies and industrial development, as well as the stability of the reserves of social resources, it is necessary to steadily increase the new cycle of industrialization in agriculture.

Keywords: agriculture; closed-cycle economy; industry development

For citation. Prodanova N.A., Savin A.A., Kosnikov S.N., Sorgutov I.V. Conceptual approaches to the development of the agricultural sector in terms of the closed-cycle economy. Siberian Journal of Life Sciences and Agriculture, 2021, vol. 13, no. 3, pp. 321-331. DOI: 10.12731/2658-6649-2021-13-3-321-331

\section{КОНЦЕПТУАЛЬНЫЕ ПОДХОДЫ К РАЗВИТИЮ СЕЛЬСКОХОЗЯЙСТВЕННОЙ ОТРАСЛИ В СВЕТЕ ЭКОНОМИКИ ЗАМКНУТОГО ЦИКЛА}

\section{Н.А. Проданова, А.А. Савин, С.Н. Косников, И.В. Соргутов}

Современный этап развития сельскохозяйственной отрасли характеризуется высокими темпами автоматизации производственных процессов. В 
той связи обостряется проблема рачионализаџии процесса распределения сельскохозяйственных ресурсов и организачии производственной цепочки с добавленной стоимостью. В качестве эффективного решения данной проблемы может выступать модель экономики замкнутого цикла. Указанная модель может способствовать рациональному использованию ресурсов, снижению производственных потерь, и, как следствие, - улучшению качества производимой продукции и ее объемов. Необходимо разработать общий план реализачии основных постулатов экономики замкнутого циикла в сельском хозяйстве, поэтапно реализовать стратегию круговой экономики и включите новую промышленную круговую экономику в процесс модернизации той или иной отрасли сельского хозяйства. В некоторых областях сельского хозяйства следует как можно скорее создать цикл производственных систем. При базовой реализачии новых промышленных технологий и промышленного развития, а также стабильности запасов социальных ресурсов необходимо неуклонно наращивать новый цикл индустриализации в сельском хозяйстве.

Ключевые слова: сельское хозяйство; экономика замкнутого цикла; развитие отрасли

Для цитирования. Проданова Н.А., Савин А.А., Косников С.Н., Соргутов И.В. Концептуальные подходы к развитию сельскохозяйственной отрасли в свете экономики замкнутого иикла // Siberian Journal of Life Sciences and Agriculture. 2021. T. 13, № 3. C. 321-331. DOI: 10.12731/2658-6649-2021-13-3-321-331

\section{Introduction}

Due to the intensive development of agricultural technologies, many countries are facing serious problems, such as the reduction of land resources and the growth of waste, which increases the risk of air and soil pollution. Therefore, the traditional agricultural model needs urgent transformation and modernization to achieve sustainable development and intensive use of resources [1]. Taking into account the territorial land features, as well as the development opportunities of the industry under consideration, a number of states apply various methods of transformation and modernization of agricultural production, such as" biological agriculture "(Western Europe)," Precision agriculture "(USA), and" Organic agriculture "(Japan).

However, taking into account the development of agricultural production technologies and the need to increase the volume of products produced, the leading countries of the world are gradually turning their attention to the need to implement the technologies used within the framework of a closed-cycle economy model. This model includes the integration of agriculture and animal 
husbandry and is a scientific, effective and organic form of planting and growing plants, developed to achieve the following goals [2]:

- environmental safety;

- production of environmentally friendly agricultural products;

- processing of agricultural waste;

- zero (minimum) emissions from agricultural activities.

Despite the positive aspects, the application of this approach faces such problems as dependence on state subsidies, secondary pollution caused by biological gases. In this regard, the optimization of the process of implementing this model becomes the object of research by a number of scientists.

\section{Materials and methods}

In the process of writing the work, articles and monographs were analyzed within the framework of the research topic. In addition, analytical and comparative methods were used.

\section{Results}

The relevance of the topic under consideration is increasing exponentially, since the demand for food products around the world is growing annually [3]. This need is compounded by the effects of climate change on agricultural systems: rising temperatures and changes in the structure of global precipitation increase the likelihood of a decrease in crop yields and the spread of weeds and pests on agricultural land [4].

The above-mentioned problems open up wide opportunities for the development of a circular economy (CE) using innovative technologies and profitable business methods to solve the problem of recycling agricultural waste, as well as by-products of the industry. The development of CE requires the introduction of closed-loop systems that work to achieve the goals of increasing economic and environmental sustainability [5]. The development of such systems is a departure from traditional linear production models that work through the transfer of natural resources to products, and then to waste [6].

$\mathrm{CE}$ assumes a certain model that does not have a net impact on the environment, providing a reduction in the use of natural resources and waste production [7], an effective reduction of waste for processing their valuable related products.

During the transition to a cyclical economy, there is a need for data collection and exchange, investment in innovation and promotion of business cooperation [8]. The transition is required at the level of the supply chain, and not at the level of an individual company, due to the need for comprehensive development 
of the system [9]. This entails the need to evaluate and redesign existing production systems, including integrated technological solutions that allow taking into account the biogeochemical and technical aspects of the circular system.

The relevance of the topic under consideration entails an increase in the number of appeals from the world's leading experts to this topic is also increasing. There are several studies devoted to the analysis of the model of agricultural circular economy. Most of them are focused on the assessment of sustainable development, which uses various methods, such as index assessment, model life cycle assessment, etc. Thus, the authors use life cycle assessment methods to compare the differences between traditional and biogas models of the circular economy of pig farms and to assess the environmental and economic benefits of carbon trading [10].

In addition, certain complex agricultural models were proposed for implementation, involving the parallel production of plant and animal products. The results of such studies, in general, prove that the model has allowed to increase the environmental, economic and sustainable advantages of the agricultural production process in comparison with the traditional model. Accordingly, integrated agriculture is a promising model of sustainable development.

Considering the planning of the agricultural development model, the authors use such methods as an analytical hierarchical process, multi-purpose linear programming, and models of system dynamics. A structure based on two-level models of agricultural production planning in arid and semi-arid regions based on fuzzy and interval confidence constraints is also presented. Of particular interest is a framework model that combines agent-based approaches and automated models of settlement growth to provide services for making decisions about a compromise between ecosystems. Accordingly, the development of approaches to the implementation of the main postulates of the closed-cycle economy in the field of agriculture entails the development and proposal of various methods for the practical implementation of integrated technologies in the field of agriculture.

\section{Discussion}

The researchers point out that the traditional model of the economy is a one-way flow of a linear economy, namely "resources $\rightarrow$ products $\rightarrow$ linear waste growth", which is based on high-intensity exploitation and consumption of resources and at the same time causes damage to the environment with high intensity. In contrast to the traditional economy, the circular economy is characterized by a low consumption of materials and resources in the production pro- 
cess, a low level of pollution, high efficiency and a significant circulation rate, which allows the full use of resources in the production process. As a result, the negative impact of economic activity on nature will be maximally reduced [11].

Thus, a cyclical economy provides economic development, environmental protection and resource savings within the same goal. Its distinctive feature is resource saving and waste recycling, which makes it an indispensable choice for any leading country in the world if it wants to change the model of economic growth from extensive to intensive.

The system of a sustainable economic cycle should have five features. First, production and consumption should, as far as possible, switch from the use of energy that causes environmental pollution to the use of renewable green energy sources. Secondly, consumption of raw materials and choosing materials suitable for recycling should be minimized. Third, one should resist packaging for the purpose of dumping goods and using packaging materials and containers that can be recycled.

Fourth, reducing the number of different types of industrial waste that must be processed as thoroughly as possible at the same time. Fifth, possibility of processing the resources of the post-consumer products industry and minimizing the number of landfills and cases of incineration of household waste should appear [12].

The requirements of a closed-cycle economy are imposed on the construction of its industrial system in three dimensions.

1. Measurement of internal turnover for the development of eco-industrial and sustainable agriculture;

2. The size of the cycle between industries for the development of an ecological production chain or an eco-industrial park (the ecological chain can even be extended to various industries, including industry, agriculture and animal husbandry).

3. Measurement of the general circulation of society for the intensification of the development of the green consumer market and the resource processing industry [13].

The introduction of a circular economy is an inevitable option for the sustainable development of agriculture. This process is the key basis of the overall national economy. There is an urgent need for the sustainable development of agriculture in order to meet the trend of the development of the circular economy.

The problems of environmental pollution, environmental damage and resource depletion in modern traditional agriculture should be resolved using the principles and methods of circular economy. 
Among the advantages of agriculture for the development of a circular economy should be called a close connection with the natural environment, respectively, agriculture is more easily accessible for the process of processing materials of natural ecosystems, which allows you to develop and implement a model of economic development based on processing

As a part of nature, agriculture participates in the entire system of circulation of materials and energy, which offers a more direct implementation path for coordinating relations between man and nature and contributes to the sustainable development of mankind, postulated by the circular economy [14].

The characteristics of agricultural industries allow us to speak about the significant advantages of agriculture, which can contribute to its development within the framework of a circular economy. The industrial system of agriculture includes many industries, including crop production, animal husbandry, forestry, fishing, processing of agricultural products, trade in agricultural products and services, which are closely interrelated and synergetic. The natural connection between the agricultural sectors and the integrated features of the structure of agriculture are the basis for the agroecological production chain created and strengthened by the cyclical economy, as well as determining the need to ensure the coordinated development of agricultural sectors [15].

Among the main principles of the closed-cycle economy in the field of agriculture, the following should be mentioned:

1. The need to follow the $3 \mathrm{R}$ principle (reduction, reuse, recycling) and the principle of primary waste reduction, which involves reducing the volume of input of limited or non-renewable resources and materials and the volume of waste production throughout the life cycle of agricultural products in the process of agricultural production in order to achieve certain production and consumption goals.

2. Reuse refers to resources or products that must be used multiple times. For example, washing water for livestock and poultry can be used for irrigation, achieving not only the effect of irrigation, but also fertilization.

3. Recycling refers to products that, after completing their function, become newly available resources, and not useless garbage. The principle of the primacy of waste reduction requires the prevention of waste in production as a priority goal of economic activity.

4. In addition, the agro-cyclical economy should support the principles of measurement adapted to local conditions, biological coexistence and mutual benefit, general coordination, maximum green cover, minimum loss of soil fertility, use and protection of land resources, reasonable flow and the best distribution of resources, rationalization of the economic structure, etc. [16]. 
Clean production, prevention and control of pollution in the process of performing basic agricultural operations is the main vector of movement in the industry under consideration.

Different agricultural sectors can also complement each other in the production chain. Thus, waste from crop production can be used in the production of building materials, paper production, etc. This will make it possible to form a complete and closed ecological industrial network for the exchange of resources for the production of new products. Also, the result of this process can be the effective use of waste and the reduction of environmental pollution due to the activation, optimization, modernization, expansion of various agricultural industries [17].

Agricultural technology systems that support the development of a circular economy should include:

1. The concept of environmentally friendly production in agriculture and the system of environmental technologies.

2. The theory of the life cycle and methods of environmental assessment

3. The concept of environmental management in agriculture and the system of environmental management methods.

4. Principles of the ecosystem and technology systems of the agricultural industry.

5. Laws and regulations of the agricultural circular economy and the implementation of the policy of preferences and the security system.

5. Models of sustainable development of the circular economy of agriculture [18].

On the basis of ecological agriculture, a model of progressive development of the processing economy should be developed in order to produce environmentally friendly agricultural products and environmentally friendly food products. Ecological agriculture of any developed country today should consist in the use of modern science and technology, traditional agricultural methods, principles of ecology and ecological economics and systems of engineering methods for the implementation of integrated planning, rational organization of agricultural production for the purpose of integrated management of low-productive areas and improving the ecological functions of high-yielding areas in accordance with local conditions and the advantages of local resources, achieving high quality, effective and sustainable development of agriculture and a favorable cycle of both ecological and economic systems, as well as effective integration of the economy, ecology and society.

It is also necessary to develop a cyclical model of the economy in the light of organic agriculture in order to develop organic food (products) and organic 
industry as a means. Organic industry refers to the ecological branch chain of organic agriculture (organic agriculture, organic forestry, animal husbandry, organic fishing), processing industry, trade and services in the field of organic agriculture.

Organic consumption is also an important factor. Based on the rejection of genetic engineering and chemically synthesized substances, such as chemical fertilizers and pesticides, in the process of agricultural production, organic agriculture follows environmental principles and ecological and economic laws to create and restore a healthy ecological circular system of agriculture. Organic agricultural products must be produced and processed in accordance with the relevant international production standards and through the certification of organic agricultural products. The development of organic agriculture and organic industry is the need to protect the environment, preserve limited resources, develop the rural economy and improve people's lives [19].

The quality of life and protection of human health is an effective way to accelerate the restructuring of agriculture and industrial modernization and effective management of the source of environmental pollution and ensure sustainable agricultural development, as well as the development of an eco efficiency economy. Therefore, it is necessary to strive to introduce a waste recycling model to promote organic agriculture as a basis, develop organic food (products) for this purpose and develop the organic food industry.

\section{Conclusion}

Since the 60s of the 20th century, people have begun to think about the limitations of traditional methods of industrial food production, which is a large consumption of natural resources and the formation of a large amount of waste. The establishment of a production cycle mode in agriculture is to turn it into a production cycle mode "resources $\rightarrow$ products $\rightarrow$ waste $\rightarrow$ renewable resources $\rightarrow$ processed products", in which various production and vital waste can fall into the reproduction zones. Thus, the use of the so-called "deep cycle" of agricultural production is being updated.

The system of technologies of cyclic production is the main part of the creation of a circular economy, which is basically a method that uses various wastes for reproduction, including decomposition, synthesis and production.

Accordingly, it is necessary to develop a general plan for the implementation of the main postulates of the closed-cycle economy in agriculture, gradually implement the circular economy strategy and include new industrial circular economy in the process of modernization of a particular branch of agriculture. In some areas of agriculture, a cycle of production systems should be established as soon 
as possible. With the basic implementation of new industrial technologies and industrial development, as well as the stability of the reserves of social resources, it is necessary to steadily increase new cycle of industrialization in agriculture.

\section{References / Список литературы}

1. Trifonova T.A., Ilyina M.E. The life cycle and its assessment as an environmental management tool: textbook. Vladimir: Arkaim, 2016, 68 p.

2. Brown M.T., Ulgiat S. Assessing the global environmental sources driving the geobiosphere: A revised emergy baseline. Ecol. Model., 2016, vol. 339, pp. 126132. https://doi.org/10.1016/j.ecolmodel.2016.03.017

3. DrobnikT., Huber R., Grêt-Regamey A. Coupling a settlement growth model with an agro-economic land allocation model for securing ecosystem services provision. J. Environ. Plann. Manag., 2017, vol. 60, no. 7, pp. 111-152. https:// doi.org/10.1080/09640568.2016.1197828

4. Feizizadeh B., Blaschke T. Land suitability analysis for Tabriz County, Iran: a multi-criteria evaluation approach using GIS. J. Environ. Plann. Manag., 2013, vol. 56, no. 1, pp. 1-23. https://doi.org/10.1080/09640568.2011.646964

5. Ilina A.I. Tsirkulyarnaya ekonomika i tsirkulyarnye biznes-modeli [Circular economy and circular business models]. Saint Petersburg State University, 2018.

6. Valko D.V. Circular economy: A theoretical model and implementation effects. National Interests: Priorities and Security, 2018, vol. 14, iss. 8, pp. 1415-1429. https://doi.org/10.24891/ni.14.8.1415

7. Galán-Martin A., Pozo C., Guillén-Gosálbez G., Vaiiejo A.A., Esteller L.J. Multi-stage linear programming model for optimizing cropping plan decisions under the new Common Agricultural Policy. Land Use Pol., 2015, vol. 48, pp. 515-524. https://doi.org/10.1016/j.landusepol.2015.06.022

8. Batova N., Sachek P., Tochitskaya I. On the Way to Green Growth: Window Opportunities of Circular Economy. BEROC Green Economy Policy Paper Series, 2018. https://beroc.org/en/publications/policy_papers/on_the_way_to_green_growth/

9. García I.F., Perea R.G., Moreno M.A., Montesinos P., Poyato E.C., J.A.R. Diaz Semi-arranged demand as an energy saving measure for pressurized irrigation networks. Agric. Water Manag., 2017, vol. 193, pp. 22-29. https://doi. org/10.1016/j.agwat.2017.07.025

10. Giri S., Nejadhashemi A.P. Application of analytical hierarchy process for effective selection of agricultural best management practices. J. Environ. Manag., 2014, vol. 132, pp. 165-177. https://doi.org/10.1016/j.jenvman.2013.10.021

11. Pakhomova N.V., Richter K.K., Vetrova M.A. Transition to a circular economy and closed supply chains as a factor of sustainable development. Bulletin of St. 
Petersburg State University. Economy, 2017, vol. 33, no. 2, pp. 244-268. https:// doi.org/10.21638/11701/spbu05.2017.203

12. Brutyan M.M., Vakhromeeva M.P., Vorozheikina T.M. et al. Problemy Sovremennoy Ekonomiki [Problems of modern economy] / ed. Chernova S.S. Novosibirsk, 2016, $262 \mathrm{p}$.

13. Houshyar E., Wu X.F., Chen G.Q. Sustainability of wheat and maize production in the warm climate of southwestern Iran: an emergy analysis. J. Clean. Prod., 2018, vol. 172, pp. 2246-2255. https://doi.org/10.1016/j.jclepro.2017.11.187

14. Tao H., Yuping W., Xiaoyue S., Xianqiang M., Liping L., Hai Y. Foreign Trade Deficit in Term of Resource-Environment and Application of Trade Practices for Achieving Environmental Goals. In: Qu F., Sun R., Guo Z., Yu F. (eds) Ecological Economics and Harmonious Society. Research Series on the Chinese Dream and China's Development Path. Springer, Singapore. 2016. https://doi. org/10.1007/978-981-10-0461-2_13

15. Yu Hong, Nico Heerink, Minjuan Zhao, Wopke van der Werf. Intercropping contributes to a higher technical efficiency in smallholder farming: Evidence from a case study in Gaotai County, China. Agric. Syst., 2019, vol. 173, pp. 317-324. http://dx.doi.org/10.1016/j.agsy.2019.03.007

16. Chunli Du, Jinhua Chen. Soft Cluster Analysis of Circular Economy Development Level in China Regions. Operations Research and Management Science, 2009, vol. 6, pp. 116-122. http://dx.doi.org/10.1109/CSO.2009.114

17. Serbulova N.M., Gorodnyanskaya A.S., Kanurny S.V. Barriers to the transition to a circular economy. Ekonomika i Predprinimatel'stvo [Economy and entrepreneurship], 2018, no. 3 (92), pp. 978-983.

18. Ruixin Mu, Integrative Evaluation and Case Study on the Development Level of Circular Economy in the city. Central South University, 2009, pp. 39-41.

19. Shaanxi Provincial Bureau of Statistics: Shaanxi Statistical Yearbook: 20052009 Beijing, China Statistical Publishing House.

\section{DATA ABOUT THE ATHORS}

\section{Natalia A. Prodanova}

Plekhanov Russian University of Economics

36, Stremyanny lane, Moscow, 117997, Russian Federation

prodanova.na@rea.ru

\section{Alexander A. Savin}

Financial University

49, Leningradsky Prospekt, Moscow, 125993, Russian Federation 
ORCID: 0000-0002-3124-4433

dr.alexander-savin@yandex.ru

\section{Sergey N. Kosnikov}

Kuban State Agrarin University named after I.T. Trubilin

13, Kalinina Str., Krasnodar, 350044, Russian Federation

snkosnikov@gmail.com

ORCID: 0000-0002-2918-8209

\section{Ilya V. Sorgutov}

Perm State Agro-Technological University named after Academician D.N. Pryanishnikov

23, Petropavlovskaya Str., Perm, 614990, Russian Federation

Sorgutov_iliya@mail.ru

ORCID: 0000-0002-3840-8648

\section{ДАННЫЕ ОБ АВТОРАХ}

\section{Проданова Наталья Алексеевна}

Российский экономический университет имени Г.В. Плеханова пер. Стремянный, 36, г. Москва, 117997, Российская Федеращия prodanova-00@mail.ru

\section{Савин Александр Алексеевич}

Финансовый университет при правительстве Российской Федераиии Ленинградский просп., 49, г. Москва, 125993, Российская Федерачия dr.alexander-savin@yandex.ru

\section{Косников Сергей Николаевич}

Кубанский государственный аграрный университет имени И.Т. Трубилина

ул. Калинина, 13, г. Краснодар, 350044, Российская Федерация snkosnikov@gmail.com

\section{Соргутов Илья Валерьевич}

Пермский государственный аграрно-технологический университет им. академика Д.Н. Прянишникова

ул. Петропавловская, 23, г. Пермь, 614990, Российская Федерачия Sorgutov_iliya@mail.ru 